\title{
KAJIAN SPASIAL DAN PARTISIPASI MASYARAKAT SEBAGAI UPAYA PENGENDALIAN BANJIR DI KABUPATEN ACEH UTARA
}

\author{
Wesli \\ Jurusan Teknik Sipil, Universitas Malikussaleh \\ email: ir_wesli@yahoo.co.id
}

\begin{abstract}
Abstrak
Setiap tahun sungai Krueng Keureuto menimbulkan bencana banjir di daerah pengalirannya terutama di kecamatan Matangkuli, Lhoksukon, Baktiya, Tanah Pasir dengan lama genangan 7 hari sampai 15 hari serta tinggi genangan $60 \mathrm{~cm}$ sampai $100 \mathrm{~cm}$. Kontradiksi antara kebutuhan lahan untuk pengembangan pembangunan wilayah dengan kebutuhan lahan yang mampu menjadi penyangga air perlu diatasi melalui suatu kajian optimasi spasial agar kedua kebutuhan tersebut dapat terpenuhi namun juga dapat mereduksi kelebihan air yang akan berakibat banjir. Disamping itu perlu dilakukan upaya partisipasi masyarakat sebagai salah satu stake holders dalam melakukan tindakan preventiv maupun mitigasi bencana banjir. Hasil penelitian memperlihatkan bahwa partisipasi masyarakat masih rendah dan kurangnya peluang yang diberikan oleh pemerintah daerah pada keikutsertaan masyarakat. Untuk penanggulangan banjir dengan pendekatan struktural (structural approach) mempunyai kecenderuangan terhadap tingginya biaya yang diperlukan sementara keterbatasan anggaran pada pemerintah daerah merupakan konstrain pada aspek tersebut sehingga perlu dilakukan strategi non structural approach dengan melibatkan masyarakat dan mengandalkan konsep modal sosial yaitu trust (kepercayaan),
\end{abstract}

Kata Kunci : Spasial, Partisipasi Masyarakat, Banjir

\section{Pendahuluan}

Banjir merupakan fenomena alam berupa kelebihan air yang menjadi limpasan permukaan akibat sungai maupun saluran-saluran yang ada (drainase) tidak mampu lagi mengalirkan air yang berlebihan tersebut. Selain itu bentuk sungai yang berliku-liku (meander) juga menyebabkan kecepatan aliran relatif rendah untuk mengalirkan air sehingga menimbulkan genangan di kiri kanan sungai, dari aspek tata ruang juga dapat berpengaruh sebagai pemicu terjadinya banjir di mana perubahan atau alih fungsi lahan hutan menjadi lahan pertanian, pemukiman atau lainya sesuai kebutuhan pembangunan daerah mengakibatkan luas daerah resapan air menjadi berkurang sehingga penyerapan air hujan ke dalam tanah menjadi kecil dan sebaliknya limpasan menjadi lebih besar. Intensitas hujan yang tinggi sebagai penyebab banjir merupakan fenomena alam yang datangnya tidak dapat dihindari sebab hal ini merupakan gejala alam yang berusaha membuat perimbangan akibat perilaku manusia, namun manusia dapat membuat perlakuan teknis terhadap alam untuk dapat mengendalikan kelebihan air tersebut sehingga mengiliminir dampaknya sekecil mungkin. Akibat tingginya intensitas hujan maka terjadi limpasan permukaan sehingga ada korelasi antara hujan dan limpasan merupakan dua fenomena yang saling terkait satu sama lainnya. Hujan merupakan fenomena alam yang tidak dapat diketahui secara pasti namun dapat dilakukan perkiraan berdasarkan data hujan terdahulu. Semakin 
banyak data hujan maka akan semakin mendekati akurasi perkiraan yang akan dilakukan. Dalam suatu perencanaan, kebutuhan data yang akurat tidak dapat dihindari sebab jika data yang ada tidak akurat niscaya hasil dari perencanaanpun tidak seperti yang diharapkan. Sebagaimana diketahui bahwa ketersediaan data di Indonesia sangat minim dan tingkat akurasinya juga rendah.

Dampak bencana banjir akan terjadi pada beberapa aspek dengan tingkat kerusakan berat. Aspek penduduk antara lain korban jiwa/meninggal, hanyut, tenggelam, luka-luka, korban hilang, pengungsian, berjangkitnya wabah dan penduduk terisolasi, sekolah terpaksa diliburkan. Aspek pemerintahan antara lain kerusakan atau hilangnya dokumen, arsip, peralatan dan perlengkapan kantor dan terganggunya pelayanan masyarakat. Aspek ekonomi antara lain hilangnya mata pencaharian, tidak berfungsinya pasar tradisional, kerusakan atau hilangnya harta benda, ternak dan terganggunya perekonomian masyarakat. Aspek Sarana /Prasarana antara lain kerusakan rumah penduduk, jembatan, jalan, bangunan gedung perkantoran, fasilitas sosial dan fasilitas umum, instalasi listrik, air minum dan jaringan komunikasi. Aspek lingkungan antara lain kerusakan eko-sistem, obyek wisata, persawahan/lahan pertanian, sumber air bersih dan kerusakan tanggul/jaringan irigasi. Dari sisi lain kebutuhan air bagi sumber kehidupan manusia merupakan dilema di mana pada waktu tertentu terjadi kekurangan air sehingga fenomena ini berbanding terbalik dengan kondisi banjir, untuk itu perlu dilakukan pengelolaan sumber daya air demi menjamin ketersediaan dan kelestarian sumber daya air.

Sungai Krueng Keureuto salah satu sungai yang melalui kota Lhoksukon tidak mampu menampung limpasan yang terjadi di Daerah Aliran Sungai (DAS) sehingga setiap tahunnya terjadi banjir yang menimbulkan kerugian besar terutama bagi masyarakat sekitar. DAS sungai Krueng Keureuto yang luasnya 931 $\mathrm{km}^{2}$ mempunyai anak sungai terdiri dari sungai Krueng Peuto dan sungai Krueng Pirak terletak di Kabupaten Aceh Utara. Sungai Krueng Keureuto mengalir dari arah selatan ke utara menuju Selat Malaka. Panjang sungai 77,5 km dan lebarnya $60 \mathrm{~m}$ serta kemiringan rata-rata (i) 0,02627. Selama ini banjir terjadi di kecamatan Matangkuli, Lhoksukon, Baktiya, Tanah Pasir dengan lama genangan 7-15 hari serta tinggi genangan 60-100 cm. Perubahan kondisi hidrologi kawasan di DAS Krueng Keureuto menyebabkan terjadinya intensitas hujan yang tinggi. Perubahan ini akibat terjadinya penebangan hutan secara tidak terkendali dan penggunaan lahan yang tidak pada peruntukannya diduga merupakan salah satu aspek penyebab terjadinya limpasan permukaan sehingga terjadi banjir. Disamping itu Perencanaan Tata Ruang Wilayah yang dilakukan oleh pemerintah daerah yang masih simpang siur dan belum adanya Qanun (Perda) sehingga perubahan tataguna lahan yang tidak terencana juga diduga merupakan penyumbang penyebab terjadinya banjir.

Pasca bencana tsunami di Provinsi Aceh, berbagai bantuan datang dari dalam dan luar negeri dan para donatur menyalurkan dananya melalui NGO dalam bentuk bantuan secara komunitas maupun perorangan khususnya bantuan langsung membuat masyarakat menjadi manja dan malas sehingga terjadi perubahan budaya yang berakibat masyarakat menjadi kurang peduli terhadap 
nilai kegotongroyongan serta aspek lainnya yang diperlukan untuk menjaga lingkungan. Kebiasaan masyarakat membuang sampah di sungai maupun di saluran merupakan rendahnya partisipasi masyarakat terhadap pencegahan bahaya banjir, hal ini menyebabkan penyempitan aliran dan pada saat terjadinya hujan air meluap dari sungai dan saluran secara berlebihan. Dari sisi penggunaan tataguna lahan, banjir sungai Krueng Keureuto juga disebabkan perubahan sebagian hutan menjadi lahan pertanian dan pemukiman sehingga penyerapan air hujan ke dalam tanah menjadi kecil dan sebaliknya limpasan menjadi lebih besar berdampak pada sosial ekonomi masyarakat dan menimbulkan kerugian juga berdampak terhadap aspek ekonomi secara kabupaten.

Untuk mereduksi banjir yang terjadi, perlu adanya suatu perencanaan spatial di kabupaten Aceh Utara seperti pengaturan komposisi tata guna lahan dengan melakukan optimasi lahan melalui peningkatan penyerapan air berdasarkan koefisien pengaliran. Terjadi kontradiksi antara kebutuhan lahan untuk pengembangan pembangunan wilayah dengan kebutuhan lahan yang mampu menjadi penyangga air. Untuk mengatasinya perlu suatu kajian optimasi tataguna lahan agar kedua kebutuhan tersebut dapat terpenuhi namun juga dapat mereduksi kelebihan air yang akan berakibat banjir. Disamping itu perlu dilakukan upaya partisipasi masyarakat sebagai salah satu stake holders dalam melakukan tindakan preventif terhadap bencana banjir termasuk pelibatan dalam pengelolaan sumber daya air dan berperan aktif dalam mencegah terjadinya banjir maupun partisipasi terhahap mitigasi ketika terjadinya banjir. Tujuan dari kajian spasial adalah sebagai upaya pengendalian banjir melalui upaya non structural dengan nengatur tataguna lahan serta meningkatkan peran aktif masyarakat baik secara individu maupun secara kelompok sehingga nantinya dapat menjadi rekomendasi bagi pemerintah daerah dalam melaksanakan pembangunan wilayah

\section{Tinjauan Kepustakaan}

\subsection{Bencana}

Menurut Peraturan Kepala Badan Nasional Penanggulangan Bencana Nomor 4 tahun 2008 tentang Pedoman Penyusunan Rencana penanggulangan bencana menyatakan bahwa Bencana adalah peristiwa atau rangkaian peristiwa yang mengancam dan mengganggu kehidupan dan penghidupan masyarakat yang disebabkan, baik oleh faktor alam dan/atau faktor nonalam maupun faktor manusia sehingga mengakibatkan timbulnya korban jiwa manusia, kerusakan lingkungan, kerugian harta benda, dan dampak psikologis. Kompleksitas dari permasalahan bencana tersebut memerlukan suatu penataan atau perencanaan yang matang dalam penanggulangannya, sehingga dapat dilaksanakan secara terarah dan terpadu. Penanggulangan yang dilakukan selama ini belum didasarkan pada langkah-langkah yang sistematis dan terencana, sehingga seringkali terjadi tumpang tindih dan bahkan terdapat langkah upaya yang penting tidak tertangani. Potensi terjadinya ancaman bencana banjir saat ini disebabkan keadaan badan sungai rusak, kerusakan daerah tangkapan air, pelanggaran tata-ruang wilayah, pelanggaran hukum meningkat, perencanaan pembangunan kurang terpadu, dan disiplin masyarakat yang rendah. 


\subsection{Daerah Aliran Sungai (DAS)}

Daerah Aliran Sungai (DAS) merupakan satu kesatuan ekosistem yang unsur-unsur utamanya terdiri atas sumberdaya alam tanah, air dan vegetasi serta sumberdaya manusia sebagai pelaku pemanfaat sumberdaya alam tersebut. DAS di beberapa tempat di Indonesia memikul beban amat berat sehubungan dengan tingkat kepadatan penduduknya yang sangat tinggi dan pemanfaatan sumberdaya alamnya yang intensif sehingga terdapat indikasi belakangan ini bahwa kondisi DAS semakin menurun dengan indikasi meningkatnya kejadian tanah longsor, erosi dan sedimentasi, banjir, dan kekeringan. Disisi lain tuntutan terhadap kemampuannya dalam menunjang system kehidupan, baik masyarakat di bagian hulu maupun hilir demikian besarnya.

Sebagai suatu kesatuan tata air, DAS dipengaruhi kondisi bagian hulu khususnya kondisi biofisik daerah tangkapan dan daerah resapan air yang di banyak tempat rawan terhadap ancaman gangguan manusia. Hal ini mencerminkan bahwa kelestarian DAS ditentukan oleh pola perilaku, keadaan sosial-ekonomi dan tingkat pengelolaan yang sangat erat kaitannya dengan pengaturan kelembagaan (institutional arrangement). Tidak optimalnya kondisi DAS antara lain disebabkan tidak adanya keterpaduan antar sektor dan antar wilayah dalam pengelolaan sumberdaya alam dan lingkungan DAS tersebut. Dengan kata lain, masing-masing berjalan sendiri-sendiri dengan tujuan yang kadangkala bertolak belakang. Sulitnya koordinasi dan sinkronisasi tersebut lebih terasa dengan adanya otonomi daerah dalam pemerintahan dan pembangunan di mana daerah berlomba memacu meningkatkan Pendapatan Asli Daerah (PAD) dengan memanfaatkan sumberdaya alam yang ada. Permasalahan ego-sektoral dan ego-kedaerahan ini akan menjadi sangat komplek pada DAS yang lintas kabupaten/kota dan lintas propinsi. Oleh karena itu, dalam rangka memperbaiki kinerja pembangunan dalam DAS maka perlu dilakukan pengelolaan DAS secara terpadu.

\subsection{Partisipasi Masyarakat}

Partisipasi masyarakat merupakan proses teknis untuk memberi kesempatan dan wewenang lebih luas kepada masyarakat, agar masyarakat mampu memecahkan berbagai persoalan bersama-sama. Pembagian kewenangan ini dilakukan berdasarkan tingkat keikutsertaan (level of involvement) masyarakat dalam kegiatan tersebut. Partisipasi masyarakat bertujuan untuk mencari solusi permasalahan lebih baik dalam suatu komunitas, dengan membuka lebih banyak kesempatan bagi masyarakat untuk memberi kontribusi sehingga implementasi kegiatan berjalan lebih efektif, efisien, dan berkelanjutan. Stakeholder penanggulangan banjir secara umum dikelompokkan menjadi tiga, yaitu Beneficiaries masyarakat yang mendapat manfaat/dampak secara langsung maupun tidak langsung, Intermediaries kelompok masyarakat atau perseorangan yang dapat memberi pertimbangan atau fasilitasi dalam penanggulangan banjir (konsultan, pakar, LSM, dan profesional di bidang SDA) dan Decision/policy makers, lembaga/institusi yang berwenang membuat keputusan dan landasan hukum, seperti lembaga pemerintahan dan dewan sumberdaya air. Sejalan dengan tuntutan masyarakat akan keterbukaan dalam program-program pemerintah, maka akuntabilitas pemerintah dapat dinilai dari sejauh mana partisipasi masyarakat dan 
pihak terkait (stakeholder) dalam program pembangunan. Partisipasi masyarakat, mulai dari tahap kegiatan pembuatan konsep, konstruksi, operasional, pemeliharaan, serta evaluasi dan pengawasan.

Terjadinya serangkaian banjir dalam waktu relatif pendek dan terulang tiap tahun, menuntut upaya lebih besar mengantisipasinya, sehingga kerugian dapat diminimalkan. Berbagai upaya pemerintah yang bersifat struktural (structural approach), ternyata belum sepenuhnya mampu menanggulangi masalah banjir di Aceh Utara. Penanggulangan banjir, selama ini lebih terfokus pada penyediaan bangunan fisik pengendali banjir. Kebijakan sektoral, sentralistik, dan top-down tanpa melibatkan masyarakat sudah tidak sesuai dengan perkembangan global yang menuntut desentralisasi, demokrasi, dan partisipasi stakeholder, terutama masyarakat yang terkena bencana. Kebijakan penanggulangan banjir yang bersifat fisik, harus diimbangi dengan langkah-langkah non-fisik, sehingga peran masyarakat dan stakeholder lainnya diberi tempat yang sesuai. Agar penanggulangan banjir lebih integratif dan efektif, diperlukan tidak hanya koordinasi di tingkat pelaksanaan, tetapi juga di tingkat perencanaan kebijakan, termasuk partisipasi masyarakat dan stakeholder lainnya. Berdasarkan uraian tersebut di atas memperlihatkan bahwa penanggulangan secara structural approach yang mempunyai kecenderuangan terhadap tingginya biaya yang diperlukan sementara keterbatasan anggaran pada pemerintah daerah merupakan konstrain pada aspek tersebut sehingga perlu dilakukan strategi non structural approach dengan melibatkan masyarakat dan mengandalkan konsep modal sosial yaitu trust (kepercayaan),

\section{Metode Penelitian}

Lokasi penelitian wilayah survey dilakukan pada 6 kecamatan yaitu Tanah Pasir, Syamtalira Aron, Tanah Luas, Matangkuli, Lhoksukon dan Baktiya, dipilih atas pertimbangan kondisi dan karakteristik daerah rawan banjir yang dicirikan dengan perbedaan intensitas banjir, jumlah dan kepadatan penduduk, serta keandalan data di wilayah studi. Data yang diperlukan pada perencanaan ini terdiri dari data teknis, data persepsi masyarakat baik secara individual maupun secara kelembagaan masyarakat dan persepsi dari aparatur pemerintah yang mempunyai tanggungjawab terhadap pengelolaan sumber daya air. Pengumpulan data yang diperlukan dilakukan sesuai dengan karakteristik data yaitu data teknis pengumpulan data dengan cara observasi lapangan dan studi dokumentasi dari dinas teknis, data persepsi masyarakat baik secara individual maupun secara kelembagaan masyarakat dan persepsi dari aparatur pemerintah yang mempunyai tanggungjawab terhadap pengelolaan sumber daya air dilakukan pengumpulannya melalui kuesioner.

Analisis data pada aspek teknis dilakukan berdasarkan data hujan yang diperoleh dari Badan Meteorologi dan Geofisika (BMG) Statiun Lhokseumawe. Berdasarkan data hujan akan diketahui hidrologi kawasan sehingga nantinya akan diperoleh debit maksimum yag akan dibandingkan dengan kapasitas tampungan baik kapasitas tampungan sungai maupun kapasitas cekungan-cekungan yang mampu menyimpan air serta akan diketahui debit limpasan yang menyebabkan terjadinya banjir. Hal ini juga akan dihubungkan dengan kondisi tataguna lahan 
yang ada. Hasil ini akan dikomparasi dengan analisa dari persepsi masyarakat. Kondisi tataguna lahan dikelompokkan berdasarkan kemampuan peresapan air melalui infiltrasi yang ditunjukkan oleh koefisien pengaliran berdasarkan lahan. Tataguna lahan eksisting selengkapnya diperlihatkan pada Tabel 1

Tabel 1 Tataguna Lahan dan Luas Genangan Banjir

\begin{tabular}{|l|r|r|c|}
\hline \multicolumn{1}{|c|}{ Lahan } & \multicolumn{1}{c|}{ Luas } & $\begin{array}{c}\text { Persentase } \\
\text { Luas (\%) }\end{array}$ & Luas Genangan \\
\hline Pemukiman \& lainnya & 5,250 & 5.64 & 64 \\
\hline Sawah, Ladang & 13,418 & 14.41 & 3,027 \\
\hline Perkebunan & 3,660 & 3.93 & 50 \\
\hline Tambak & 1,362 & 1.46 & 1,659 \\
\hline Hutan & 69,410 & 74.55 & 437 \\
\hline Jumlah Sumber: Aztindo Reka Perdana (1997) \\
\hline \multicolumn{4}{|c|}{$\mathbf{5 3 , 1 0 0}$} \\
\hline
\end{tabular}

Analisis tataguna lahan secara proporsional dilakukan dengan metode optimasi menggunakan Linear Programming, dibantu software Quantitative System (QS). Dari survei dan kajian literatur tersebut akan diperoleh data tentang kebijakan dan program penanggulangan banjir, peraturan perundangan terkait penanggulangan banjir, kondisi satuan wilayah sungai, sistem pengelolaan sumberdaya air, kebijakan penanggulangan banjir yang diterapkan, kendala dalam penanggulangan banjir, serta partisipasi masyarakat dalam penanggulangan banjir baik pada in-stream maupun offstream. Hasil survei dan kajian literatur tersebut akan dipetakan terhadap kebijakan dan regulasi dan partisipasi masyarakat dalam penanggulangan banjir.

\section{Pembahasan}

Upaya penanggulangan banjir yang selama ini dilakukan lebih terfokus pada penyediaan bangunan fisik pengendali banjir. Untuk mengurangi dampak bencana perlu adanya upaya lain dalam penanganan banjir melalui pendekatan pengendalian kawasan rawan banjir yaitu: Pengendalian Struktural (pengendalian terhadap banjir) pelaksanaan pengendalian ini dilakukan melalui kegiatan rekayasa teknis, terutama dalam penyediaan prasarana dan sarana serta penanggulangan banjir, Pengendalian Non Struktural (pengendalian terhadap pemanfaatan ruang) kegiatan ini dilakukan untuk meminimalkan kerugian yang terjadi akibat bencana banjir, baik korban jiwa maupun materi, yang dilakukan melalui pengelolaan daerah pengaliran, pengelolaan kawasan banjir, flood proofing, penataan sistem permukiman, sistem peringatan dini, mekanisme perijinan, serta kegiatan lain yang berkaitan dengan upaya pembatasan (limitasi) pemanfaatan lahan dalam rangka mempertahankan keseimbangan ekosistem.

Pada upaya pengendalian structural melalui rekayasa teknis, pemerintah daerah sudah membuat perencanaan pembangunan Waduk Krueng Keureto dengan biaya yang cukup Rp. 800 Milyar yang rencana pembangunannya dimulai pada tahun 2014. Berdasarkan dokumen perencanaan teknis yang sudah dilakukan, waduk ini hanya dapat mereduksi banjir sebesar $60 \%$ yang bermakna bahwa masih akan terjadi peluang banjir sebesar $40 \%$. 
Perencanaan spasial mengupayakan aspek pengendalian Non Struktural melalui upaya pemanfaatan ruang melalui penataan tataguna lahan dengan optimasi yang nantinya dapat mereduksi debit maksimum. Konsep tataguna lahan tidak serta merta dapat dilakukan dalam waktu yang singkat karena perlu waktu untuk mengendalikan tataguna lahan tersebut sehingga upaya pengendalian perlu perhatian dari multy stakeholders untuk komit dalam implementasinya. Dari hasil analisis kondisi hidrologis kawasan berdasarkan data curah hujan selama 15 tahun dapat dikatakan bahwa tingginya curah hujan menyebabkan tingginya debit kawasan yang menyebabkan kelebihan air, tidak dapat ditampung lagi oleh saluran yang ada sehingga menyebabkan terjadinya banjir. Besaran debit maksimum periode ulang di kawasan tersebut diperlihatkan pada Tabel 2

Kebutuhan terhadap ruang sebagai wadah kegiatan pembangunan dirasakan semakin meningkat, hal ini antara lain disebabkan meningkatnya jumlah dan jenis kegiatan pembangunan yang membutuhkan ruang. Tanpa perencanaan atau penataan yang memadai, kegiatan dimaksud akan menimbulkan konflik dalam pemanfaatan ruang dan ada kecenderungan pemanfaatan sampai pada taraf dimana aspek konservasi lingkungan tidak lagi diperhatikan. Oleh karenanya perencanaan ruang mutlak diperlukan dan diharapkan akan dapat berfungsi sebagai arahan spasial bagi semua kegiatan pembangunan agar pemanfaatan ruang yang serasi dan optimal dapat dicapai.

Tabel 2 Debit Maksimum Periode Ulang

\begin{tabular}{|c|c|c|c|r|}
\hline $\begin{array}{c}\text { PERIODE } \\
\text { ULANG }\end{array}$ & $\mathbf{R}_{\mathbf{2 4}}$ & $\mathbf{I}_{\mathbf{T}}$ & $\begin{array}{c}\text { Koef. Alir DAS } \\
(\mathbf{C})\end{array}$ & $\begin{array}{c}\mathbf{Q} \\
\left(\mathbf{m}^{\mathbf{3}} / \mathbf{d e t}\right)\end{array}$ \\
\hline 5 & 98.69 & 8.8 & 0.43 & 979.37 \\
\hline 10 & 115.27 & 10.28 & 0.47 & $1,250.51$ \\
\hline 25 & 136.22 & 12.15 & 0.52 & $1,635.21$ \\
\hline 50 & 151.76 & 13.54 & 0.54 & $1,892.37$ \\
\hline 100 & 167.19 & 14.91 & 0.56 & $2,161.03$ \\
\hline
\end{tabular}

Kondisi eksisting tataguna lahan berdasarkan kecamatan yang merupakan rawan banjir di kabupaten Aceh Utara diperlihatkan pada Tabel 3

Tabel 3 Tataguna lahan Kabupaten Aceh Utara Pada DAS Kr. Keureuto

\begin{tabular}{||l|r|r|r|r|r|r|r||}
\hline \multirow{3}{*}{ Kecamatan } & \multicolumn{7}{|c||}{ LUAS MENURUT PENGGUNAAN LAHAN (Ha) } \\
\cline { 2 - 9 } & $\begin{array}{c}\text { Pemukim } \\
\text { a }\end{array}$ & $\begin{array}{c}\text { Sawah, } \\
\text { Ladang }\end{array}$ & $\begin{array}{c}\text { Perkebu } \\
\text { nan }\end{array}$ & Tambak & $\begin{array}{c}\text { Hutan } \\
\text { Lebat }\end{array}$ & $\begin{array}{c}\text { Luas } \\
\text { Wilayah }\end{array}$ & \multicolumn{1}{c||}{$(\%)$} \\
\hline \hline Tanah Pasir & 466.96 & $1,379.96$ & & $1,636.58$ & & $3,483.50$ & $\mathbf{3 . 7 4}$ \\
\hline Syamtalira Aron & 675.80 & $2,060.34$ & & & & $2,736.14$ & $\mathbf{2 . 9 4}$ \\
\hline Tanah Luas & 829.67 & $2,671.64$ & 588.18 & & & $4,089.49$ & $\mathbf{4 . 3 9}$ \\
\hline Matangkuli & $3,323.61$ & $13,777.46$ & $21,424.03$ & & & $38,525.10$ & $\mathbf{4 1 . 3 8}$ \\
\hline Lhoksukon & $1,447.39$ & $10,478.23$ & $11,759.54$ & & & $23,685.16$ & $\mathbf{2 5 . 4 4}$ \\
\hline Baktiya & $1,248.44$ & $6,743.22$ & $5,719.66$ & 492.34 & & $14,203.66$ & $\mathbf{1 5 . 2 6}$ \\
\hline DAS & & & & & $6,376.93$ & $6,376.93$ & $\mathbf{6 . 8 5}$ \\
\hline \hline Jumlah & $7,991.87$ & $37,110.85$ & $39,491.41$ & $2,128.92$ & $6,376.93$ & $93,099.98$ & $\mathbf{1 0 0 . 0 0}$ \\
\hline \hline Persentase (\%) & $\mathbf{8 . 5 8}$ & $\mathbf{3 9 . 8 6}$ & $\mathbf{4 2 . 4 2}$ & $\mathbf{2 . 2 9}$ & $\mathbf{6 . 8 5}$ & $\mathbf{1 0 0 . 0 0}$ & \\
\hline
\end{tabular}


Hasil analisis terhadap proporsi tataguna lahan memperlihatkan bahwa makin kecilnya lahan hutan sebagai penyangga air melalui kekuatan resapan mengakibatkan jumlah debit semakin meningkat sementara kebutuhan akan lahan pembangunan tidak dapat dihindari seiiring dengan meningkatnya kegiatan wilayah. Untuk memenuhi kebutuhan lahan pembangunan sekaligus dapat meruduksi terjadinya banjir maka perlu direncanakan optimasi tataguna lahan secara proporsional dan spasial wilayah seperti diperlihatkan pada tabel 4

Tabel 4 Hasil Optimasi Tataguna Lahan dan Debit Yang Terjadi

\begin{tabular}{|c|c|c|c|c|c|c|}
\hline \multirow[t]{2}{*}{ Lahan } & \multicolumn{2}{|c|}{$\begin{array}{c}\text { Luas Lahan } \\
\text { Existing }\end{array}$} & \multicolumn{2}{|c|}{\begin{tabular}{|c} 
Luas Lahan RUTR \\
Kabupaten
\end{tabular}} & \multicolumn{2}{|c|}{\begin{tabular}{|l} 
Luas Lahan \\
Hasil Optimasi
\end{tabular}} \\
\hline & $(\mathbf{k m 2})$ & $(\%)$ & \begin{tabular}{|l|}
$(\mathbf{k m} 2)$ \\
\end{tabular} & $(\%)$ & \begin{tabular}{|l|}
$(\mathbf{k m} 2)$ \\
\end{tabular} & $(\%)$ \\
\hline Pemukiman \& lainnya & 52.5 & 5.64 & 79.88 & 8.58 & 79.88 & 8.58 \\
\hline Sawah, Ladang & 134.18 & 14.41 & 371 & 39.85 & 201.38 & 21.63 \\
\hline Perkebunan & 36.6 & 3.93 & 394.93 & 42.42 & 325.84 & 35 \\
\hline Tambak & 13.62 & 1.46 & 21.32 & 2.29 & 21.32 & 2.29 \\
\hline Hutan & 694.1 & 74.55 & 63.87 & 6.86 & 302.58 & 32.5 \\
\hline Jumlah & 931 & 100 & 931 & 100 & 931 & 100 \\
\hline $\begin{array}{c}\text { Debit Yang Terjadi } \\
\left(\mathrm{m}^{3} / \mathrm{det}\right)\end{array}$ & \multicolumn{2}{|c|}{$1,686.16$} & \multicolumn{2}{|c|}{$1,944.96$} & \multicolumn{2}{|c|}{$1,835.68$} \\
\hline
\end{tabular}

Dari penelusuran data ditemukan bahwa penyebab banjir relatif sama meskipun dengan intensitas yang berbeda, yaitu curah hujan tinggi, jumlah dan kepadatan penduduk tinggi, pengembangan daerah yang tidak terkendali dan tidak sesuai tata ruang serta tidak berwawasan lingkungan sehingga menyebabkan berkurangnya daerah resapan dan tampungan air, drainase kota yang tidak memadai akibat sistem drainase yang kurang tepat dan kurangnya prasarana darinase, dan kurangnya pemeliharaan, luapan sungai besar yang mengalir ke tengah kota, kerusakan lingkungan pada daerah hulu, kondisi pasang air laut pada saat hujan sehingga mengakibatkan backwater, berkurangnya kapasitas pengaliran sungai akibat penyempitan sungai dan penggunaan lahan illegal di bantaran sungai, kurang lancar hingga macetnya aliran sungai karena tumpukan sampah serta ketidakjelasan status dan fungsi saluran. Upaya penanggulangan banjir tidak terlepas dari peran stakeholder dalam setiap kegiatan. Dari hasil survei diketahui bahwa secara umum peran stakeholder terutama penerima dampak bencana (beneficiaries) masih terbatas dan peran pemerintah masih sangat dominan. Hasil survey memperlihatkan bahwa pada tahap pra bencana, partisipasi masyarakat berupa keikutsertaannya pada kegiatan sosialisasi berbagai peraturan, membangun atau membersihkan saluran drainase lingkungan secara swadaya, memprakarsai lomba kebersihan, menjaga dan memantau kondisi lingkungan belum terlaksana dengan baik

Pada saat terjadi bencana terjadi kerjasama yang baik dalam evakuasi korban, pembagian makanan, pakaian, dan penyediaan obat-obatan. Partisipasi masyarakat seperti ini muncul secara spontan sebagai bentuk kepedulian sosial sesama masyarakat tanpa diupayakan oleh pemerintah. Dengan belum tersedianya peraturan daerah (Qanun) yang mengatur penanggulangan banjir, maka pengaturan partisipasi masyarakat juga belum diatur. Pendanaan penanggulangan banjir sebagian besar masih sangat tergantung pada pemerintah. Optimalisasi sumber pendanaan dari masyarakat meskipun potensinya cukup besar masih belum dikelola secara baik dan hanya mencakup pembiayaan bantuan spontan yang bersifat charity dan perbaikan kecil prasarana lingkungan secara swadaya. 
Secara umum penyebab utama banjir adalah perubahan dan eskalasi perilaku manusia dalam mengubah fungsi lingkungan, kawasan budidaya terjadi perubahan tata ruang secara massive sehingga daya dukung lingkungan menurun drastis. Pesatnya pertumbuhan permukiman mengubah keseimbangan fungsi lingkungan, bahkan kawasan retensi banjir (retarding basin) juga dihabiskan. Keadaan ini secara signifikan telah menurunkan secara drastis kapasitas penyerapan air dan diperparah dengan penyediaan sistem drainase permukiman yang kurang memadai sehingga pada curah hujan tertentu sudah menimbulkan genangan air di mana-mana. Penambangan pasir illegal terutama pada areal-areal sekitar bangunan sungai yang umumnya mudah diakses juga ikut memperparah keadaan karena kemampuan bangunan sungai menjadi menurun.

Di sisi lain pada wilayah survey secara umum belum ada implementasi kebijakan yang efektif untuk mengendalikan penggundulan hutan dan perubahan fungsi ruang pada daerah hulu. Aktivitas dan perubahan ini makin meningkatkan debit air yang masuk langsung dan secara cepat ke badan sungai, pada akhirnya karena kapasitas tampung dan pengaliran sungai telah menurun maka terjadi peluapan air sungai ke kawasan permukiman, persawahan, dan pertambakan. Secara umum hasil survei menunjukkan bahwa tidak ada landasan hukum spesifik yang mengatur tentang penanggulangan banjir, demikian pula halnya pengaturan partisipasi masyarakat. Temuan yang menggembirakan adalah partisipasi masyarakat terutama pada kegiatan tanggap darurat di mana bersama dengan kelompok stakeholder dari unsur intermediaries masyarakat membentuk "gugus tugas reaksi cepat" yang secara mandiri dan tanpa intervensi pemerintah mampu memberikan bantuan darurat bagi para korban banjir. Hal ini menunjukkan bahwa partisipasi masyarakat tersebut lebih didorong semangat kesetiakawanan dalam bermasyarakat, bukan merupakan resultant dari upaya pemerintah.

Dalam implementasinya, tidak teridentifikasi partisipasi masyarakat dalam pelaksanaan konstruksi dan umumnya dilaksanakan oleh penyedia jasa konstruksi. Pada tahap monitoring dan evaluasi hanya teridentifikasi peran pemerintah daerah dalam melakukan monitoring dan evaluasi terhadap prasarana off-stream structural measure, sedangkan partisipasi masyarakat secara langsung tidak ditemukan.

\section{Kesimpulan}

Berdasarkan analisis yang dilakukan terhadap data yang telah dikumpulkan dan diolah dapat disimpulkan

1. Spasial melalui optimasi tataguna lahan dapat mereduksi debit maksimum pada kawasan DAS sungai Krueng Keureto sehingga dapat mengurangi terjadinya besaran banjir

2. Partisipasi masyarakat sebagai salah satu stakeholder masih sangat kurang, peran pemerintah masih sangat dominan pada setiap tahapan bencana. Partisipasi masyarakat yang merupakan critical player pada tahapan sebelum bencana memiliki pengaruh yang sangat kecil dalam proses dan implementasi kebijakan. Tingkat partisipasi terbaik yang terjadi baru pada tingkat consultation. Bahkan pada beberapa kegiatan masih pada tingkat information di mana masyarakat masih sebagai obyek suatu program/kegiatan pemerintah. 
3. Kebijakan pemerintah daerah tentang penanggulangan bencana masih sangat terbatas. Peran daerah terbatas pada kegiatan prevention. Sedangkan kebijakan pada saat bencana menggunakan pedoman-pedoman yang dikeluarkan oleh pemerintah pusat, dan belum dalam bentuk peraturan daerah. Demikian halnya pada tahapan rehabilitasi pasca bencana.

4. Peraturan perundangan terutama di daerah masih terbatas. Dengan demikian penegakan hukum juga belum banyak dilakukan. Penegakan hukum hanya dilakukan pada penggunaan lahan secara ilegal

Rekomendasi yang dapat diberikan perlu kajian lebih detil terhadap nonstructural approach malalui perencanaan spasial terhadap tataguna lahan, memberi peluang yang lebih besar terhadap partisipasi masyarakat dalam berbagai aspek, membuat kebijakan publik dalam bentuk qanun terhadap penanggulangan banjir

\section{Daftar Kepustakaan}

1. Anonim, 2004, Revisi Rencana Tata Ruang Kabupaten Aceh Utara, Pemerintah Kabupaten Aceh Utara, Aceh Utara

2. Anonim, 2004, Undang-undang Republik Indonesia Nomor 7 tahun 2004 tentang Sumber Daya Air, Republik Indonesia

3. Anonim, 2008, Pedoman Pengendalian Pemanfaatan Ruang di kawasan Rawan Bencana Banjir, Bapppenas, Jakarta

4. Asdak, Chay, M.Sc., Ph.D, 2002, Hidrologi dan Pengelolaan Daerah Aliran Sungai, Gajah Mada University Press, Yogyakarta

5. Aztindo Reka Perdana, PT, 1997, Buku Data SWS 01.03. Pase Peusangan, Kanwil Departemen Pekerjaan Umum Propinsi Daerah Istimewa Aceh, Banda Aceh

6. Chow, V.T., Maidment, D.R., Mays, L.W, 1988, Applied Hydrology, Mc Graw Hill Book Company

7. Soemarto, C.D., 1993, Hidrologi Teknik, Erlangga, Jakarta

8. Soewarno, 1995, Hidrologi - Aplikasi Metode Statistik Untuk Analisa Data, Jilid II, Nova, Bandung

9. Taha, H.A., 1993, Riset Operasi, Binarupa Aksara, Jakarta

10. Wesli, 2007, Penanganan Banjir Berdasarkan Tataguna Lahan dengan Optimasi Linear Programming (Studi Kasus Krueng Keureuto, Lhoksukon), Proceedings The 2nd International Conference on Development of Aceh, ISBN: 978-979-1372-08-4, LPPM Unimal, Lhokseumawe

11. Wesli, 2008, Drainase Perkotaan, Graha Ilmu, Yogyakarta

12. Wesli, 2008, Hubungan Hujan Dengan Limpasan Untuk Penentuan Debit, Proceedings The 3rd International Conference on Development of Aceh (ICDA-3), ISBN: 979-1372-37-4, LPPM Unimal, Lhokseumawe 